\title{
METHODOLOGICAL ASPECTS OF TEACHER TRAINING FOR THEATRICAL ACTIVITIES WITH PUPILS
}

\author{
Natalia Kazmirchuk \\ Vinnytsia Mykhailo Kotsiubynskyi State Pedagogical University, Ukraine \\ Iryna Baranovska \\ Vinnytsia Mykhailo Kotsiubynskyi State Pedagogical University, Ukraine \\ Nataliia Mozgalova \\ Vinnytsia Mykhailo Kotsiubynskyi State Pedagogical University, Ukraine \\ Olga Shcholokova \\ Dragomanov National Pedagogical University, Ukraine \\ Vadym Podorozhnyi \\ Vinnytsia Mykhailo Kotsiubynskyi State Pedagogical University, Ukraine
}

\begin{abstract}
The research was conducted as part of the project of Erasmus + (Module Jean Monnet) "EU experience of soft skills development of preschool and primary school age children by theatre activities in teacher training".

The purpose of the article is to find out the educational value of theatrical activities, to reveal the methodological aspects of preparing teachers for theatrical activities with pupils.

The study used theoretical methods: analysis of psychological and pedagogical literature, synthesis, comparison, method of modeling and generalization of research results; diagnostic methods: interview, survey, observation, interview: methods of processing experimental data for quantitative and qualitative analysis of the results of diagnostic tests.

The concept of "theatrical activity" is specified, the educational and developmental potential of theatrical activity is revealed, the technique of introduction of theatrical activity in practice of modern school is developed, methodical bases of preparation of teachers for theatrical activity with schoolchildren are opened.

The results of empirical research have shown that most teachers do not use theatrical activities in their own pedagogical practice. Only certain elements are introduced in art and language lessons: staging of literary works or songs. We are convinced that theatrical activities are a powerful effective means of moral, aesthetic, promotes the development of social skills (soft skils), because it allows to involve students in various types of artistic creativity: literary, musical, visual, stage, choreographic. Through participation in theatrical performances, creative potential is revealed, high moral values are formed, sufficient communication skills are needed to model social behavior in the children's team, in the family and society as a whole. The study allowed to confirm the importance and practical feasibility of using theatrical activities as a means of education and development of youth.
\end{abstract}

Keywords: theatrical art, theatrical activity, teacher training, schoolchildren, methods. 
Kazmirchuk et al., 2021. Methodological Aspects of Teacher Training for Theatrical Activities with Pupils

\section{Introduction}

The success of the development of modern society largely depends on the creativity and activity of people and the conditions that are created for the development of each individual. That is why the «National Doctrine of Education Development of Ukraine in the XXI Century» emphasizes the need to develop the ability to creative self-expression, the formation of skills to perform creative tasks. A special role in this process belongs to the primary level of education, where the child's abilities are purposefully identified and developed, skills and desire to learn are formed, conditions are created for his self-expression in various activities.

Modern children prefer video, cartoons, computer games. They love the art of film, animation, children are one of the largest audiences of video content on the Internet, and they are trying to create their own video. At the same time, the theater, unfortunately, remains on the sidelines. Through theatrical art children get direct experience of compassion, empathy and communication, explore the expression of the audience and their own expression as an actor, which is extremely relevant today and is embodied in the reforms of the New Ukrainian School.

Reforming the education system, in turn, necessitates changes in the training of future teachers, who must be ready to implement all the innovations of the New Ukrainian school.

The purpose of the article is to find out the educational value of theatrical activities, to reveal the methodological aspects of preparing teachers for theatrical activities with students.

The study used theoretical methods: analysis of psychological and pedagogical literature, synthesis, comparison, method of modeling and generalization of research results; diagnostic methods: conversation, survey, observation, interview; statistical: methods of processing experimental data for quantitative and qualitative analysis of the results of diagnostic tests.

\section{Literature Review}

Theatrical art is the first kind of art that a child encounters. At the present stage of development of education by means of theatrical activity a number of pedagogical problems are solved: development of creative activity (Kostiushko, 1999), creative development of personality (Demchenko, 2002), formation of value orientations (Yeskina, 2001), moral and aesthetic education of preschoolers and schoolchildren (Baranovska, 2019), aesthetic development (Holinska, 2005), formation of emotional sphere (Shevchuk, 2000), formation of aesthetic culture (Sierykh, 2008), formation of spiritual culture of personality (Boryshevskyi, 
Pylypenko, \& Penkova, 2013), education of teenagers by means school puppet theater (Churylina, 1995), preparation of future primary school teachers for the organization of theatrical activities of junior students (Solomakha, 1995), the formation of junior students' interest in learning through theater pedagogy (Chervinska, 2014).

Modern scientists (Baranovska, Mozghalova, \& Kazmirchuk, 2020) in their research focus on the educational and developmental value of theatrical activities, in particular: «at the stage of revival and acquaintance with the puppet the child develops the mechanism of self-regulation, show their feelings. Because of emotional decentralization, children easily begin to communicate».

At the same time (Zhovnych, Kazmirchuk, \& Stakhova, 2020) in their research claim that «theatrical activities, in particular, nature theater, promote the development of soft skills of primary school children, manifested in the skills of listening and hearing each other, collaborating, seeking information and carrying responsibility for its authenticity, to present one's work, to be creative in solving the set tasks, to use one's own time rationally, and so on».

In research (Demchenko \& Zaitseva, 2017) were identified a number of categories of problem gifted primary school students, among which there is a category of socially gifted students with acting talent, which are characterized by such personal qualities as: demonstrativeness, failure; developed acting, public speaking, management skills. These students have a high sociometric status and a wide range of communication, they are leaders in the team, but at the same time constantly in conflict with teachers, initiate a collective violation of discipline; experiencing a state of frustration and unrealization. Such children, unfortunately, will remain unrealized without getting into the theatrical environment. Therefore, one of the tasks of teachers is the need to involve children in theatrical activities.

Analyzing the modern psychological, pedagogical and methodological literature on the stated research problem, we can say that the use of theatrical activities in education has long troubled scientists, but the vast majority of theatrical activities were considered a form of extracurricular activities for children. Scientists of the twentieth century have a lot of achievements on this issue. Because at that time the society formed respect and interest in theater, amateur theater studios and clubs functioned at schools, which periodically demonstrated the results of their work. In modern society, unfortunately, the theater has remained on the sidelines. Children and adults live in a technical virtual world, while theater can teach children "live" communication and help them integrate into public life. Today, in the methodological literature there are many author's developments of ways to involve preschool children in theatrical activities, while almost no modern literature is aimed at introducing theatrical activities in school practice and training future teachers to implement it. 
Kazmirchuk et al., 2021. Methodological Aspects of Teacher Training for Theatrical Activities with Pupils

Theatrical art occupies an important place among the means of influencing the formation of the personality of junior schoolchildren. This special integrated art form organically combines artistic word, dramatic action, poetics, painting, music and choreography. It helps the child to know himself more deeply, his inner world, encourages him to self-improvement, evoking in the course of theatrical action aesthetic feelings and emotions, forming attitudes to moral actions, cultivating moral qualities.

Most educators and psychologists today agree that theatrical activities are one of the effective way of mastering basic competencies by students. In the process of comprehending the moral and emotional subtext of a literary work, participation in theatrical activities, favorable conditions are created for artistic and aesthetic education of holistic development and education of students. Students develop independent creativity and self-expression, self-knowledge and looseness, correct and improve communication skills, cultivate the will, develop memory, imagination, initiative. In the process of theatrical activity, a positive mood is created, tension is relieved, conflict situations are resolved through play, and feelings of a «success situation» are realized.

By participating in the play, the child masters the role-playing game, learns social roles, learns to solve life problems and gains a positive experience in communicating with peers and adults. The whole life of children is full of play. Every child wants to play a role, and theater helps students not to be afraid to try on roles and embody them. Perseverance in theatrical activities encourages students to study and discover their own «I».

The dialogue of the heroes of the play contains instructive content, important information and social norms. The main feature of any theatrical action is the ability to entertain the audience, as well as encourage them to think. Therefore, children, regardless of whether they are actors or spectators, are unconsciously exposed to educational influence, acquire useful knowledge and learn to draw the right conclusions. In addition, the speech of the characters is enriched with literary words, because it is based on works of art, which has a positive effect on the expansion and enrichment of the child's vocabulary. Bright images of puppets and dynamic actions with them help to concentrate and hold the attention of students. The content of the play is clear to children, so it is perceived quite easily. They love to communicate with the characters, answer questions, help solve problems for the character.

Theater occupies an important place in society and performs artistic and aesthetic, entertainment, communicative, socializing, compensatory, game, regulatory, developmental, educational and other functions. However, one of the most important functions of the theater is cognitive. It provides the transfer of social experience from the older generation to the younger, from one country and nation to another. 
In the pedagogical literature we find different interpretations of the concept of «theatrical activity». In our opinion, theatrical activity is an artistic and playful activity related to the perception of works of theatrical art, creation of artistic images, disclosure of their characters, by modeling behavior, reproducing the relationship between the characters through special verbal and nonverbal means. This is a type of creative and playful activity of a child, which allows to satisfy his needs in self-expression, communication, self-knowledge through the reproduction of various artistic images.

\section{Results of the Research}

In order to study the real state of use of theatrical activities in the practice of primary school, we conducted a statement experiment, which was attended by 88 third-graders, 12 primary school teachers and 62 3rd year students majoring in «Primary Education» in Vinnytsia Mykhailo Kotsiubynskyi State Pedagogical University (further - Pedagogical University). The experiment consisted of four stages.

The purpose of the first stage of the experiment was to analyze the existing curricula for primary school and teaching aids. We can state that in the Typical educational program for primary school (Shyian, 2019) one of the semantic lines of language and literature education is «Theatricalization», which involves primary school students in theatrical activities. In addition, within the integrated course «I explore the world», namely in the textbook of the author's team (Voloshchenko et al., 2018) for 1st grade students to get acquainted with theatrical art in the thematic week «Theater».

The aim of the second stage was to study the attitude of students to the theater, the level of their interest in theatrical activities and the level of awareness of theatrical art. At this stage, the method of questionnaires and pedagogical observation was used. Summarizing the results of the survey give the right to draw the following conclusions:

- students are interested in theatrical activities, because they are very enthusiastic about theatrical performances, about $50 \%$ of respondents are happy to participate in mini-performances, staging and dramatization of literary works;

- $\quad 100 \%$ of third graders were in the puppet theater, but only half of the students attended the play in the theater itself. Most students attended theater performances organized at a preschool or school, and only $20 \%$ of students were with their parents in a «real» theater; 
Kazmirchuk et al., 2021. Methodological Aspects of Teacher Training for Theatrical Activities with Pupils

- $\quad 35 \%$ of 3rd grade students do not know the rules of conduct in the theater, and about $80 \%$ do not know what the attributes of the theater are called;

- $\quad 45 \%$ of the subjects correctly named the types of puppets.

The aim of the third stage of the experiment was to survey primary school teachers about the use of theatrical activities in their own practice. The interview method was used at this stage. Summarizing the results, we can draw the following conclusions:

- $\quad$ primary school teachers spontaneously and sporadically use elements of theatrical activities, involve students in theatrical activities mainly during the organization of extracurricular educational activities, various holidays,

- teachers are convinced that the organization of theatrical activities takes a lot of time, and the intensity of the presentation of educational material according to the curriculum makes this process impossible;

- teachers prefer the intellectual development of students;

- $\quad$ assessing their own level of readiness to organize theatrical activities with students, $55 \%$ of teachers rated it as «insufficient» because they rarely visit the theater, are unfamiliar with new theatrical art, do not have the skills to create scripts and rehearsal process, do not always know how to select musical accompaniment, making costumes and scenery, feel insecure in the role of the actor, do not know their level of acting skills, namely do not know how to evaluate their plasticity, facial expressions and gestures;

- $\quad 72 \%$ of respondents are interested in professional development on this issue, as they see the need for it.

The purpose of the fourth stage of the observational experiment was to determine the level of readiness of future teachers to organize theatrical activities in primary school. The experiment involved 62 third-year students of the Pedagogical University. As a result, we identified three groups of skills:

- the first group of skills is associated with mastering the position of «spectator» (the ability to be a friendly spectator, mastery of the rules of conduct in the theater, awareness of famous actors, directors of their locality);

- the second group of skills provides the formation of the position of «artist» (the ability to use means of expression (facial expressions, gestures, posture, movements, strength and timbre of voice) to convey the image of the hero, his emotions and experiences, to be able to make a puppet «alive»); 
- $\quad$ the third group - is the ability to perform the role of «director», as the teacher is responsible for creating the script, the correct distribution of roles, organization of the rehearsal process, selection of costumes, scenery, musical accompaniment, etc.

To develop and improve the identified skills, we used the method of creating mini-performances by students. The following criteria and indicators were used to determine the levels of readiness of students to organize theatrical activities with students:

- motivational (interest in theatrical activities (puppet theater), desire to participate in various games, play with puppets, desire to listen to fairy tales and view illustrations, interest in the new);

- cognitive (knowledge of elementary theatrical terminology, the ability to observe, imitate and transmit animal behavior, use some means of expression (facial expressions, gestures, posture, movements, strength and timbre of voice, tempo of speech) to convey the image of the hero, his emotions and experiences, correctly «to lead» a puppet or a figure of the hero in the director's theatrical play, thank to artists);

- $\quad$ activity (the ability to be a friendly spectator, watch and listen to the end, the ability to interact with other participants in the game, play together, do not quarrel, perform attractive roles in turn, the ability to voice your character).

Based on these criteria, the levels of readiness of students to organize theatrical activities with students were determined:

- low level, students with this level - no interest in theatrical activities, passivity when listening to works of art, no desire to participate in theatrical activities, no creative satisfaction from this type of activity, the need for help in creating a script, the use of ready-made scripts; uncertainty in the selection of scenery, attributes, music, low level of acting skills;

- $\quad$ medium level - such students are active in the game and tasks, show a marked interest in theatrical performances with puppets, they are somewhat difficult to perform with the transformation into another image; show dexterity, independence, flexibility, originality in performing sketches-tasks, sometimes need help from classmates; have certain difficulties in organizing theatrical performances, in particular difficulties in adapting the work of art to the stage realization, selection of all necessary attributes, have certain problems with the manifestation of their own acting skills;

- $\quad$ high level, such students - active and proactive in the classroom, show initiative, quickly and with interest and without assistance perform 
Kazmirchuk et al., 2021. Methodological Aspects of Teacher Training for Theatrical Activities with Pupils

sketches-tasks, show the ability to interpret works of art, create scripts, cope with the role of director, know how to organize the rehearsal process, quickly and qualitatively select scenery, costumes and musical accompaniment to the play or action, perfectly master the elements of acting skills.

Of the 62 respondents (3rd year students of the inpatient department of the specialty 013 Primary Education), the generalized indicators of readiness of future primary school teachers to organize theatrical activities with students in the school were as follows: high level - 8 people (13\%), medium level - 16 people $26 \%)$, low level - 38 people (61\%).

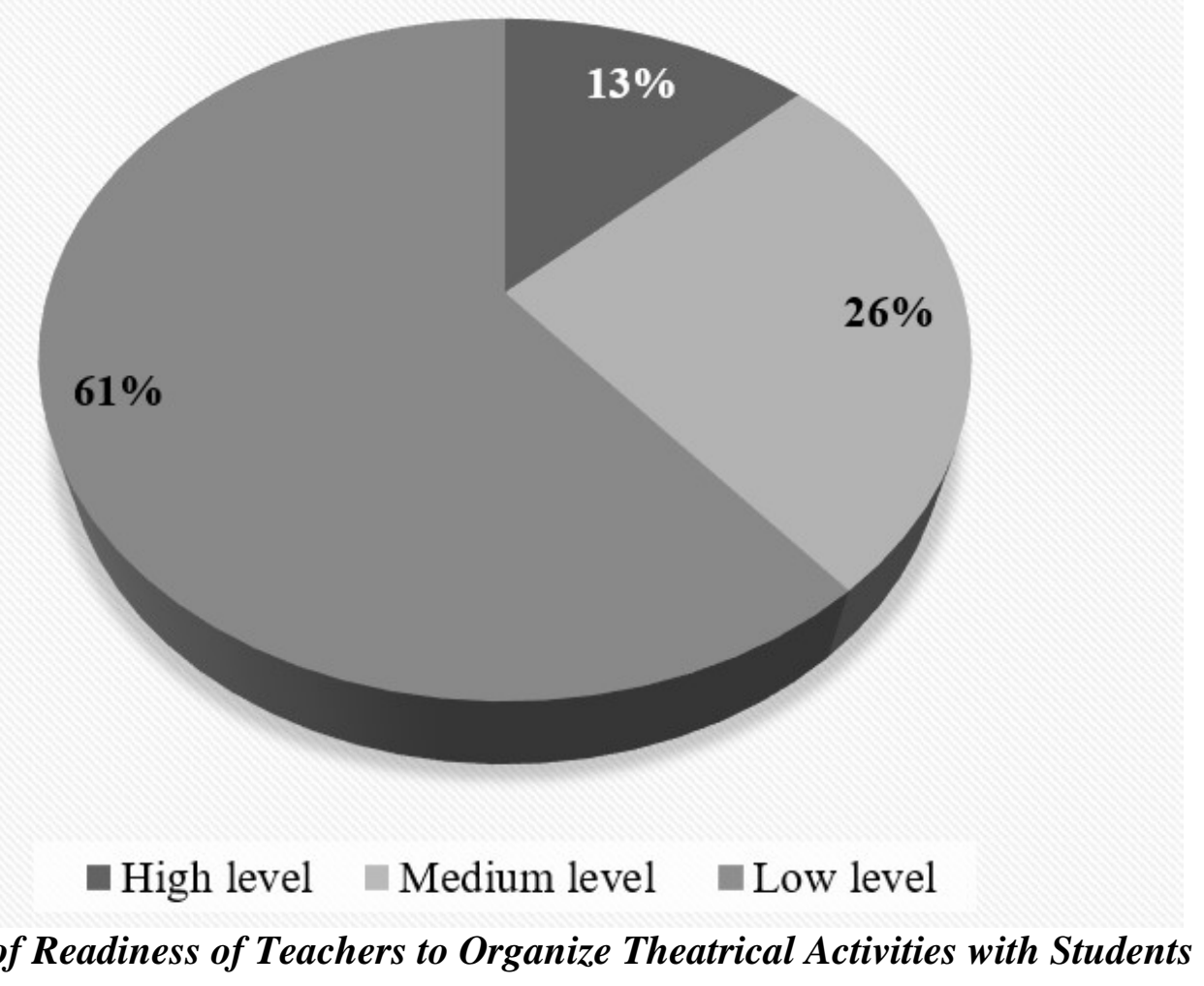

Figure 1 Levels of Readiness of Teachers to Organize Theatrical Activities with Students

From the above it can be concluded that more than half of future teachers are not ready to implement theatrical activities in the practice of primary school, and such activities are already in the typical educational programs. Such results confirm the imperfection of the current curricula of higher pedagogical education institutions, traditional methods and forms of training future teachers. We are convinced of the need to update the curricula of the institutions of higher education, to include disciplines aimed at improving various types of teacher skills, including expanding knowledge about the history of theatrical art, methodological aspects of organizing theatrical activities with students. 
This prompted us to develop and implement the educational project ERASMUS + (JEAN MONNET MODULE) 620252-EPP-1-2020-1-UAEPPJMO-MODULE «EU experience of soft skills development of preschool and primary school age children by theater activities in teacher training» on the basis of Vinnytsia State Pedagogical University named after Mykhailo Kotsyubynsky (erasmusplus.org.ua., 2020).

The project aims to provide theoretical and practical training of future preschool teachers and primary school teachers to use theatrical activities to develop soft skills of different categories of children and meaningful organization of their leisure activities based on the experience of pedagogical concepts of Western Europe. In November 2020, after the signing of the Grant Agreement, comprehensive and fruitful work began on the implementation of the project in accordance with the developed program. The target group consists of 30 students, obtaining a degree of «bachelor» in the field of knowledge 01 Education/Pedagogy specialty 012 Preschool Education, 013 Primary Education, who expressed a desire to participate in the project. Students take an optional module consisting of several interdisciplinary courses.

One of them is a training course «Fundamentals of directing and artistic and musical design of theatrical action: the European context». The purpose of this course is to acquaint students with the basics of directing and artistic and musical design of theatrical action. During the classes, students will be introduced to the European traditions of modern drama for children. This course will promote progressive pedagogical concepts and experiences of cultural and educational institutions of the European Union.

In the course of teaching we conducted lectures and practical classes with the participation of directors, actors and artists of the Vinnytsia Academic Regional Puppet Theater «Golden Key» (Vinnytsia), students attended theater performances as part of the annual International Festival of Puppet Theaters «Podilska Lyalka» (Vinnytsia) and performances of the Vinnytsia Regional Academic Ukrainian Music and Drama Theater named after M. Sadovsky (Vinnytsia). In addition, during the implementation of this project, we used such forms of organizing student learning activities as:

1) Pedagogical training. The training involves not only the acquisition of knowledge, skills and abilities in a specially created pedagogical environment, but also the practical reflection of their own experience, taking into account psychological problems. That is, trainings contribute to the development of attention, improvement of figurative memory and mastering the mechanisms of thinking and speaking, perception of the world around, creating a holistic picture of person, his place in society and in nature. As the main methods of training we recommend using language-plastic training exercises aimed at the 
Kazmirchuk et al., 2021. Methodological Aspects of Teacher Training for Theatrical Activities with Pupils

development of stage speech and stage plasticity. Each student created his own individual map, which characterized his own speech, plasticity, facial expressions and gestures. This provided an opportunity to analyze one's own problems, discuss them in small groups or pairs, and identify ways to overcome them.

2) Master class. This form of teaching is a generalization and dissemination of the best pedagogical experience. We involved in master classes of primary school teachers and educators of preschool institutions who had a good experience of theatrical activities with children. Master classes were held both on the basis of the Pedagogical University and in the usual conditions of schools and preschools. Master classes, as a rule, helped to increase the motivation of students to implement theatrical activities with students during teaching practice.

3) Socio-game workshop. Within the socio-game workshop, joint activities were combined with motor activity. The main methods we used were: improvisation; playing pedagogical and life situations in a microgroup, as well as creating one story between several microgroups, when one group begins and the other and the following continue the plot; creation of own plots of instructive character; showing miniperformances.

\section{Conclusions}

Educational and developmental opportunities for theatrical activities are wide. This is an opportunity to reveal the creative potential of the child, the development of associative thinking, the ability to see the unusual in everyday life, the development of speech (monologue and dialogue), improving sound culture, vocabulary enrichment. Theatrical activities are a source of development of feelings, deep experiences of the child, it develops socio-emotional sphere of the child through empathy for the characters and empathy when playing the event. The shortest way to the emotional looseness of the child, the removal of isolation, feeling and artistic imagination - is the way through play, fantasizing, writing.

Despite the significant scientific and methodological material accumulated by theatrical pedagogy in the field of education, there are still many methodological problems associated with the preparation of future teachers to organize theatrical activities with students, as evidenced by the results of the cost experiment. We found that more than half of future primary school teachers are not ready to organize theatrical activities with students. Since theatrical activities are already included in the standard program of primary education, it is necessary to change approaches to the training of future primary school teachers in pedagogical educational institutions as soon as possible. 
We see this in the introduction into the educational process of higher education institutions of practice-oriented training courses that will provide quality theoretical and methodological training of future teachers, their own development and self-realization in theatrical activities. One of the options to solve this problem is the implementation of the educational project ERASMUS + (MODULE JEAN MONNET) 620252-EPP-1-2020-1-UA-EPPJMO-MODULE «EU experience of soft skills development of preschool and primary school age children by theater activities in teacher training» (erasmus.vspu.edu.ua., 2020).

The purpose of this educational project is to prepare future teachers for the use of the pedagogical potential of theatrical art, the experience of European countries in implementing forms, methods, elements of theatrical art in the educational process of primary school. This approach will contribute to the humanization of education through the innovative use of theatrical technologies focused on the values of national and European culture, which are inherent in modern democratic societies.

\section{References}

Baranovska, I. (2019). Metodychni zasady khudozhno-estetychnoho vykhovannia molodshykh shkoliariv u pozaurochnyi chas. Aktualni problemy mystetskoi pidhotovky maibutnoho vchytelia, 10-14.

Baranovska, I., Mozghalova, N., \& Kazmirchuk N. (2020). Repetytsiinyi protses yak prostir dlia tvorchoi samorealizatsii ta rozvytku soft skills studentiv ta ditei. Aktualni problemy mystetskoi pidhotovky maibutnoho vchytelia, 15-21.

Boryshevskyi, M.I., Pylypenko, L.I., \&Penkova, O.I. (2013). Vykhovannia dukhovnosti osobystosti. Kirovohrad: Imeks-LTD.

Chervinska, I.B. (2014). Formuvannia u molodshykh shkoliariv interesu do navchannia zasobamy teatralnoi pedahohiky. Uzhhorod.

Churylina, L. M. (1995). Moralno-estetychne vykhovannia pidlitkiv zasobamy shkilnoho teatru lialok. Doctor's thesis. Kyiv, Ukraine: APN Ukrainy.

Demchenko, I.I. (2002). Rol khudozhnoi diialnosti u formuvanni tvorchoi osobystosti molodshoho shkoliara. Visnyk Kharkivskoi derzhavnoi akademii dyzainu i mystetstva, 12, 50-53.

Demchenko, O., \& Zajceva, O. (2017). Odarennyj rebenok kak lichnost' s osobymi potrebnostjami $\mathrm{v}$ inkljuzivnom prostranstve uchebnogo zavedenija. Proceedings of International Scientific Conference Society. Integration. Education, II, Rezekne, RTA, 61-71.

Erasmus.vspu.edu.ua. (n.d.). Retrieved from http://erasmus.vspu.edu.ua/

Erasmusplus.org.ua. (2020). Project ERASMUS + (JEAN MONNET MODULE) 620252EPP-1-2020-1-UA-EPPJMO-MODULE «EU experience of soft skills development of preschool and primary school age children by theater activities in teacher training» on the basis of Vinnytsia State Pedagogical University named after Mykhailo Kotsyubynsky Retieved from https://erasmusplus.org.ua/en/10-novyny/3381-participation-within-theiv-all-ukrainian-conference-on-inclusive-education-as-an-individual-trajectory-of- 
Kazmirchuk et al., 2021. Methodological Aspects of Teacher Training for Theatrical Activities with Pupils

personal-growth-of-a-child-with-special-educational-needs-within-the-jean-monnetproject-10-11-12-2020-online.html

Holinska, T. M. (2005). Estetychnyi rozvytok molodshykh shkoliariv zasobamy syntezu mystetstv. Doctor's thesis. Kherson, Ukraine: Khersonskyi derzh. un-t.

Kostiushko, H. O. (1999). Rozvytok tvorchoi aktyvnosti molodshykh shkoliariv zasobamy teatralnoi samodiialnosti. Extended abstract of Candidate's thesis. Kyiv, Ukraine : Nats. ped. un-t im. M.P.Drahomanova.

Ministerstva osvity i nauky Ukrainy. (2019). Typova osvitnia prohrama pochatkovoi osvity Tsykl I (1-2 klasy) Nakaz Ministerstva osvity i nauky Ukrainy osvity i nauky Ukrainy vid 08.10.2019 roku № 1272. Retrieved from https://nus.org.ua/news/opublikuvaly-typoviosvitni-programy-dlya-1-2-klasiv-nush-dokumenty/

Shevchuk, T. O. (2000). Formuvannia emotsiino-pochuttievoi sfery molodshykh shkoliariv u khudozhno- ihrovii diialnosti Doctor's thesis. Uman, Ukraine: Umanskyi derzh. pedahohichnyi un-t im. Pavla Tychyny.

Sierykh, L. V. (2008). Formuvannia estetychnoi kultury molodshykh shkoliariv u protsesi teatralizovanoi diialnosti. Doctor's thesis. Kyiv, Ukraine: In-t probl. vykhovannia APN Ukrainy.

Solomaha, S. (1995). Podgotovka buduschih uchiteley nachalnyih klassov k rukovodstvu teatralnoy deyatelnostyu mladshih shkolnikov. Extended abstract of Candidate's thesis. Kyiv, Ukraine: Instytut pedahohiky i psykholohii profesiinoi osvity APN Ukrainy.

Voloshchenko, O.V., Kozak, O.P., \& Ostapenko, H.S. (2918). Ya doslidzhuiu svit: pidruchnyk intehrovanoho kursu dlia 1 klasu zakladiv zahalnoi serednoi osvity. Kyiv: Svitych.

Yeskina, H. O. (2001). Formuvannia tsinnisnykh oriientatsii molodi zasobamy amatorskoho teatru. Doctor's thesis. Kyiv, Ukraine: Kyivskyi natsionalnyi un-t kultury i mystetstv.

Zhovnych, O.V., Kazmirchuk, N.S., \& Stakhova I.A. (2020). Teatr pryrody yak zasib formuvannia soft skills $\mathrm{v}$ uchniv pochatkovykh klasiv. Naukovi zapysky Vinnytskoho derzhavnoho pedahohichnoho universytetu imeni Mykhaila Kotsiubynskoho. Seriia: Pedahohika i psykholohiia, 61, 23-30. 